\title{
PATIENTS WITH SUSPECTED METAL IMPLANT ALLERGY: POTENTIAL CLINICAL PICTURES AND ALLERGOLOGICAL DIAGNOSTIC APPROACH (REVIEW)
}

\author{
P. Thomas ${ }^{1}$, M. Thomsen², V. Krenn ${ }^{3}$, B. Summer ${ }^{1}$ \\ ${ }^{1}$ Department of Dermatology and Allergology, Ludwig-Maximilians-University, Munich \\ ${ }^{2}$ DRK Hospital, Orthopedics and Trauma Surgery, Baden-Baden \\ ${ }^{3}$ Center for Histology, Cytology and Molecular Diagnostics, Trier \\ Germany
}

The focus of this review are allergic complications following insertion of metallic orthopedic implants. Such potential allergic reactions encompass eczema, impaired wound and fracture healing, infection-mimicking reactions, effusions, pain and loosening. Nickel, cobalt and chromium seem to be the predominant eliciting allergens. Allergy might be considered prior to planned orthopaedic surgery or in patients with complications following arthroplasty. We recommend, that differential diagnoses - in particular infection should always be excluded in cooperation with surgery collegues. The clinical work up of a patient suspected of suffering from metal implant allergy should include a combined evaluation of medical history, clinical findings, patch testing and histology. In vitro testing, namely the lymphocyte transformation test (LTT), can indicate metal sensitization, but needs careful interpretation.

Key words: allergy, metal, implant, arthroplasty, patch test, histology, lymphocyte, LTT.

\section{ПАЦИЕНТЫ С ПОДОЗРЕНИЕМ НА АЛЛЕРГИЮ К МЕТАЛЛИЧЕСКИМ ИМПЛАНТАТАМ: ВОЗМОЖНАЯ КЛИНИЧЕСКАЯ КАРТИНА И ДИАГНОСТИЧЕСКИЙ АЛЛЕРГОЛОГИЧЕСКИЙ ПОДХОД (ОБЗОР ЛИТЕРАТУРЫ)}

\author{
П. Томас ${ }^{1}$, М. Томсен ${ }^{2}$, В. Кренн ${ }^{3}$, Б. Суммер ${ }^{1}$ \\ ${ }^{1}$ Мюнхенский университет им. Людвига-Максимилиана, кафедра дерматологии и аллергологии, г. Мюнхен \\ ${ }^{2}$ DRK Клиника, отделение травматологии и ортопедии, г. Баден-Баден \\ ${ }^{3}$ Центр гистологии, иитологии и молекулярной диагностики, г. Трир \\ Германия
}

Темой данного обзора являются аллергические осложнения после установки металлических ортопедических имплантатов. Такие потенциальные аллергические реакции включают экзему, замедленное заживление ран и переломов, псевдо-воспалительные реакции, выделения, боли и расшатывание имплантата. Представляется, что самыми сильными аллергенами являются никель, кобальт и хром. Аллергию можно заподозрить до планового ортопедического вмешательства и у пациентов с осложнениями артропластики. Мы рекомендуем совместно с хирургами исключить другие диагнозы, особенно, инфекции. Клинический подход к пациенту с подозрением на аллергию к металлическим имплантатам должен включать всестороннюю оценку анамнеза, клинические данные, кожные пробы и гистологию. Анализ in vitro, в частности реакция бластной трансформации лимфоцитов (РБТЛ), может выявить чувствительность к металлу, хотя и требует тщательной интерпретации.

Ключевые слова: аллергия, металл, имплантат, артопластика, кожная проба, гистология, лимфоциты, РБТЛ.

\section{Introduction}

The prevalence of nickel, cobalt or chromium allergy is high both in the professional environment and in the general population [23]. Metal exposue may happen by skin contact with articles of daily life and increasingly also by metal implants. Metal-allergic reactions can thus appear for example as eczema but also as chronic peri-implant inflammation with pain, effusion or loosening [2, 29]. In Germany alone in the year 2011232.320 total hip and 168.486 total knee endoprostheses were implanted - and about $10.4 \%$ respectively
$9.5 \%$ of these surgeries were complication-related revision surgery [35]. Often a classical complication elicitor like malposition or infection cannot be found $[8,10]$ - and metal allergy is discussed as differential diagnosis.

Over the years implant-associated skin reactions or loosening have been described in case reports. However the causal link between the clinical picture and diagnosis of allergy remained often unclear. While only a few research groups in North America - especially J. Hallab's group - are working on the topic implant allergy, 
there is some more activity in Europe [3, 13, 34]. The Danish research group around J. Thyssen has recommended extensive patch testing (including previously not widely evaluated metal preparations) to clarify intolerance reactions [34]. The orthopedic group led by Donatella Granchi from Bologna gave a critical comment on "metal hypersensitivity testing in patients undergoing joint replacement" based on 22 publications [13]. She points out that in patients with implant failure compared to stable implant more frequently metal allergy is found. However, detection of allergy is not able to predict implant failure. In fact, there are patients who tolerate the respective implanted alloy despite the presence of cutaneous metal allergy [27]. Accordingly a general pre- or postoperative "allergy screening" is not recommended and a spectrum of potential causes for implant failure has to be considered in arthroplasty-related complications before an allergologic work-up [10]. Peri-implant inflammation patterns - apart from innate immune reactions [5] - may indicate the postulated lymphocytic hypersensitivity reaction at the joint [16, 33]. Also the "philosophy" of arthroplasty seems different [6] in Europe and the United States: For example reagarding the use of metal-on-metal (MoM) hip replacement or the use of ceramic components. Register data are not only helpful to detect high rates of complications and/ or failure of certain metal implant designs, but can give also indication of potential problem elicitors. The Australian arthroplasty register named also "metal sensitivity" as a reason for revision: in about $0.9 \%$ of the revised shoulder endoprostheses and $5.7 \%$ of the revised total hip arthroplasty [21].

As we run a special ambulatory for patients with suspected implant allergy in Munich we have seen a spectrum of implant related complications. In the following we want to inform about clinical pictures and allergy diagnostics in suspected implant allergy.

\section{Clinical pictures}

Here we focus on orthopaedic-surgical metal implants.

\section{Skin reactions}

Eczema was observed especially after osteosynthesis of the extremities in association with nickel, chromium or cobalt allergy [4, 15, 29]. In addition recurrent erysipelas-like erythema, swelling and impaired wound healing are described [32]. Erysipelas mimicking vasculitis-like reactions have been reported [18]. Also remaining metal fragments or particles related to saw-/drilling instruments may cause local allergy-related complications. The persistent erythema, itching and swelling of the big toe of a nickel-allergic patient with osteotomy is exemplary. Symptoms remained even after removal of the Kirschner wire. Radiology showed saw-wear particles in the previous surgery site [11]. Also nickel contamination of (according to manufacturer's instructions) pure titanium osteosynthesis could provoke local complications [31]. Local or generalized allergy related eczema is rarely seen in knee or hip replacement [30] as well as cutaneous vasculitis [19]. On the other hand, in case of failure of non-cemented MoM hip arthroplasty, the possible relevance of a metal allergy could be corroborated in conjunction with peri-implant histology [28]. Histological examination of implantassociated skin changes is recommended in order to not overlook rare findings such as reticular erythema [1] or intralymphatic histiocytosis [14].

\section{Other reactions}

In association with metal allergy impaired wound and fracture healing have been described [31]. Especially in knee arthroplasty recurrent pain, effusion, loosening and reduced range of motion without infection but with associated metal allergy are reported [8]. This also applies to patients with hip arthroplasty. Such cases were interpreted as metal implant allergy in synopsis of proven metal allergy and peri-implant lymphocytic inflammation particularly in patients with MoM pairing. The chain of evidence becomes better if appropriate patients are followed up after revision with "alternative materials" [3, 7]. For a number of situations the role of metal allergy, however, is still to be determined: Aseptic loosening of endoprosthesis with implant-related osteolysis; persistent pain; persistent inguinal pain and cystic "pseudotumor" development after resurfacing with metal-metal bearing; exaggerated periarticular fibrosis ("arthrofibrosis"] with restricted range of motion.

\section{Allergological diagnostics in patients with putative metal implant allergy}

\section{"Suspected allergy" before surgery}

Preoperative "prophylactic-prophetic" compatibility testing should not be performed. This matches also with the statement in the guideline of patch testing with contact allergens by Schnuch et al. [24]: "The patch test is not suitable, to predict the development of allergic contact dermatitis (in the sense of a "prophetic testing")". Only when history of previous intolerance reactions existst, a possible metal allergy or potential allergy to bone cement components can be clarified. The review article by Geier et al. [12] stresses - and this is still valid that there is yet no consensus recommendation for patch test details in suspected implant intolerance. 
Work up in patients suspected of having metal implant allergy

After exclusion of the most frequent differential diagnoses (such as infection or skin changes by psoriasis, tinea, alternative contact allergy triggers) the patch test is performed. The histology of peri-implant tissue can give an additional indication of a hypersensitivity reaction by lymphocyte dominated inflammation. A T-cellular metal sensitivity can also be questioned by the lymphocyte transformation test (LTT). This is however still restricted to scientific laboratories which evaluate the results critically case by case for the clinical relevance [29]. Figure 1 suggests the appropriate diagnostic steps.

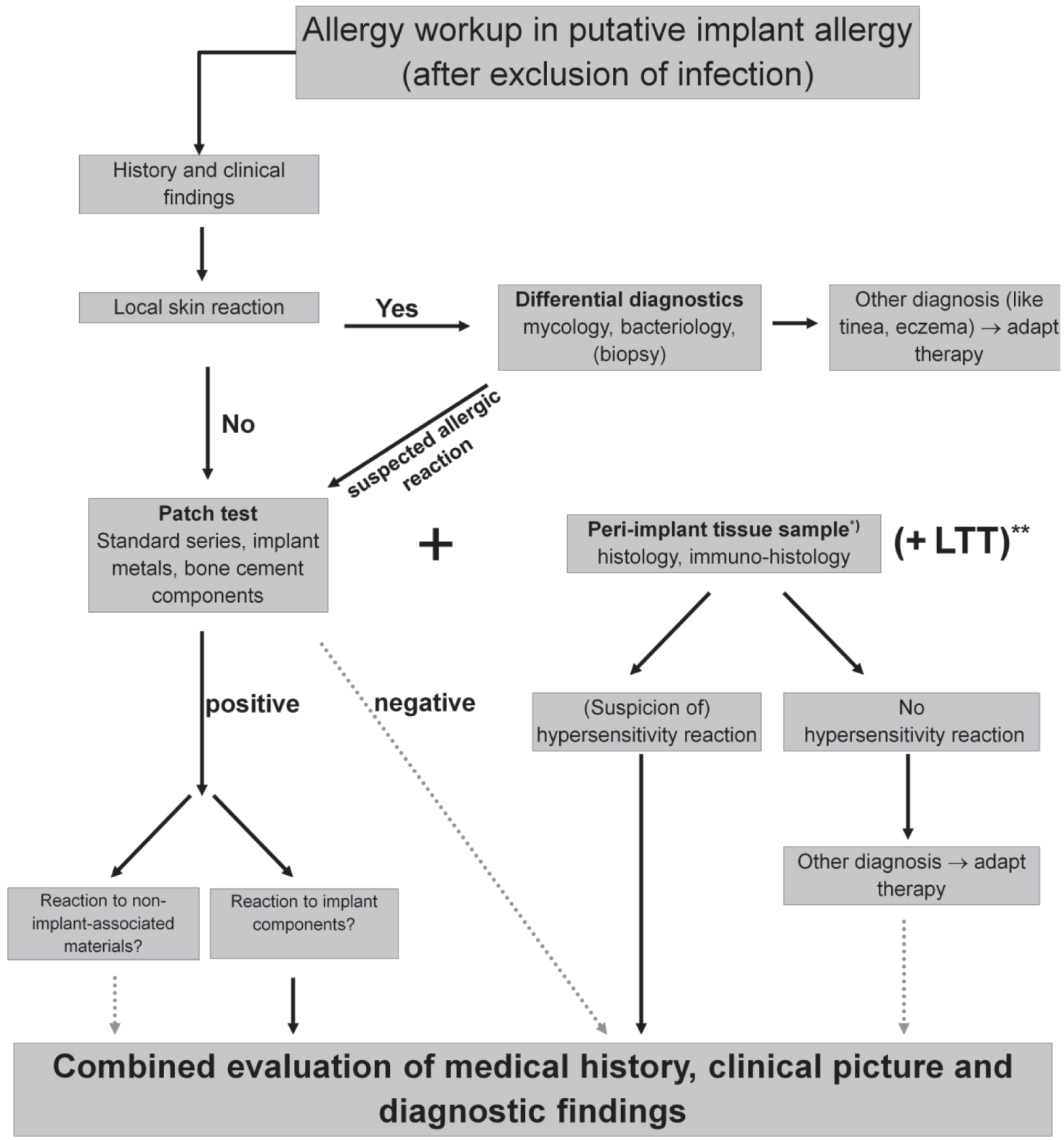

*) Immuno-histological criterias as well as a specific cytokine pattern for peri-implant hypersensitivity reaction are under investigation.

${ }^{* *}$ ) LTT can be performed in parallel. Still scientific assay, clinical significance has to be evaluated case by case

LTT, lymphocyte transformation test

Fig. 1. The algorithm for determining the hypersensitivity to implant materials after arthroplasty 


\section{Allergological medical history}

In addition to indications of a potential metal allergy (redness, itching, eczema to jeans button, to fashion jewelry or intolerance of leather goods) also intolerance of dental resins or artificial acrylatebased finger nails could be hints to possible contact allergy to acrylates and additives such as benzoyl peroxide (and a corresponding testing be justified).

\section{Patch testing}

The standard series covers with nickel, chromium and cobalt preparations essential implant components. The author's approach to suspected bone cement allergy is: testing of substances that are available from other (dental) test series: "gentamicin sulfate, benzoyl peroxide, hydroquinone, 2-hydroxyethylmethacrylate, copper-(II)-sulfate, methylmethacrylate, $\mathrm{N}$, N-dimethyl-p-toluidine". We recommend also a delayed reading after six or seven days, as we often observe late reactions to gentamicin. Additional metal preparations are available, but not yet standardized - and their use should be critically decided case by case [28]. The clinical relevance of test results must, as always, be interpreted in the context of additional informations.

\section{Histology}

The consensus classification of periprosthetic membrane reaction pattern gives very useful information [17]. A definition of metal allergyinduced peri-implant reaction pattern is currently being developed, and the author is cooperating in this matter with the reference pathologist of allergy research group of the German orthopedic and surgery society. In combination with the consensus classification of peri-implant membrane the analysis of the local cytokine pattern further adds to develop tools for evaluation of peri-implant lymphocytic inflammation [33].

\section{Lymphocyte transformation test (LTT)}

It analyzes the antigen-induced proliferative response in relation to the baseline proliferation of unstimulated peripheral blood cells in vitro. This then expressed as stimulation index [SI]. We have - as well as other laboratory groups - set the indication-limit for sensitization on $\mathrm{SI}>3$ [26] and give interpretation only in conjunction with other diagnostic parameters. The LTT can be used as a complementary method to assess antigen-specific T-cell reactions, for example when investigating a suspected allergic drug reaction [20]. It must be however carefully evaluated whether the found sensitization also means disease-causing hypersensitivity [9, 22]. Even for nickel allergy quality assessments of LTT procedures are very rare
[25]. Accordingly, the Robert Koch Institute (RKI) [9], did not publish a general recommendation for the LTT.

\section{Conclusions}

The diagnosis "implant allergy" results from the synopsis of as many diagnostic steps as possible. This starts with medical history and includes clinical findings, patch testing and analysis of periimplant tissue - with patch testing and histology appearing essential to us. The LTT is still a more scientific method and requires a thoughtful interpretation.

\section{Conflict of interest:}

This scientific article is scientifically independent and product-neutral.

\section{References}

1. Aneja S., Taylor J.S., Billings S.D., Honari G., Sood A. Post-implantation erythema in 3 patients and a review of reticular telangiectatic erythema. Contact Dermatitis. 2011; 64(5):280-288.

2. Basko-Plluska J.L., Thyssen J.P., Schalock P.C. Cutaneous and systemic hypersensitivity reactions to metallic implants. Dermatitis. 2011; 22(2):65-79.

3. Bircher A., Friederich N.F., Seelig W., Scherer K. Allergic complications from orthopaedic joint implants: the role of delayed hypersensitivity to benzoyl peroxide in bone cement. Contact Dermatitis. 2012; 66(1):20-26.

4. Brehler R.G. J., Eichelberg D. Nickelallergie nach Plattenosteosynthese. Akt Dermatol. 1990;16:2.

5. Caicedo M.S., Samelko L., McAllister K., Jacobs J.J., Hallab N.J. Increasing both CoCrMo-alloy particle size and surface irregularity induces increased macrophage inflammasome activation in vitro potentially through lysosomal destabilization mechanisms. Journal of orthopaedic research: official publication of the Orthopaedic Research Society. 2013; 31(10):1633-1642.

6. Claes L., Kirschner P., Perka C., Rudert M., eds. AE-Manual der Endoprothetik, Bd XVI. Hüfte und Hüftrevision. Heidelberg - Dordrecht - London New York: Springer; 2012.

7. Dietrich K.A., Mazoochian F., Summer B., Reinert M., Ruzicka T., Thomas P. Intolerance reactions to knee arthroplasty in patients with nickel/cobalt allergy and disappearance of symptoms after revision surgery with titanium-based endoprostheses. J. Dtsch. Dermatol. Ges. 2009; 7(5):410-413.

8. Eben R., Walk R., Summer B., Maier S., Thomsen M., Thomas P. Implant allergy register - a first report. Orthopäde. 2009; 38(6):557-562.

9. Eis D.W. "Qualitätssicherung beim Lymphozytentransformationstest" - Addendum zum LTT-Papier der RKI-Kommission "Methoden und Qualitätssicherung in der Umweltmedizin". Bundesgesundheitsblatt Gesundheitsforschung Gesundheitsschutz. 2008; 51:1070-1076.

10. Fitzgerald S.J., Trousdale R.T. Why knees fail in 2011: patient, surgeon, or device? Orthopedics. 2011; 34(9):e513-515. 
11. Gabel M.S., Thomas P. Persistierende Entzündung nach Großzehenkorrekturoperation bei einer Patientin mit Nickelallergie: Manifestation einer Überempfindlichkeit gegen Metallpartikel? Fuß \& Sprunggelenk. 2008; 6:5.

12. Geier J., Lessmann H., Becker D., Thomas P. Allergy diagnostics in suspected implant intolerance: practical approach. A position paper of the German Contact Dermatitis Research Group (DKG). Hautarzt. 2008; 59(7):594-597.

13. Granchi D., Cenni E., Giunti A., Baldini N. Metal hypersensitivity testing in patients undergoing joint replacement: a systematic review. J. Bone Joint Surg. 2012; 94-B(8):1126-1134.

14. Grekin S., Mesfin M., Kang S., Fullen D.R. Intralymphatic histiocytosis following placement of a metal implant. J. Cutan. Pathol. 2011; 38(4):35135-3.

15. Kanerva L., Forstrom L. Allergic nickel and chromate hand dermatitis induced by orthopaedic metal implant. Contact Dermatitis. 2001; 44(2):103-104.

16. Krenn V., Morawietz L., Kienapfel H., Ascherl R., Matziolis G., Hassenpflug J. et al. Revised consensus classification. Histopathological classification of diseases associated with joint endoprostheses. Z Rheumatol. 2013; 72(4):383-392.

17. Krenn V., Otto M., Morawietz L., Hopf T., Jakobs M., Klauser W. et al. Histopathologic diagnostics in endoprosthetics: periprosthetic neosynovialitis, hypersensitivity reaction, and arthrofibrosis. Orthopäde. 2009; 38(6):520-530.

18. Kulichova T., Schaefer T., Kendoff D., Summer B, Parvizi J., Thomas P. Metal hypersensitivity mimicking periprosthetic erysipelas-like infection. J. Bone Joint Surg. Case Connector. 2014; accepted.

19. McKenzie A.W., Aitken C.V., Ridsdill-Smith R. Urticaria after insertion of Smith-Petersen Vitallium nail. Br. Med. J. 1967; 4 (5570):36.

20. Pichler W.J., Tilch J. The lymphocyte transformation test in the diagnosis of drug hypersensitivity. Allergy. 2004; 59(8):809-820.

21. Australian Orthopaedic Association National Joint Replacement (AOANJR) Registry. Annual Report. 2009.

22. Renz H., Becker W.M., Bufe A., Kleine-Tebbe J., RaulfHeimsoth M., Saloga J. et al. In vitro allergy diagnosis. Guideline of the German Society of Asthma and Immunology in conjunction with the German Society of Dermatology. J. Dtsch. Dermatol. Ges. 2006; 4(1):72-85.

23. Schafer T., Bohler E., Ruhdorfer S., Weigl L, Wessner D., Filipiak B. et al. Epidemiology of contact allergy in adults. Allergy. 2001; 56(12):1192-1196.

24. Schnuch A., Aberer W., Agathos M., Becker D., Brasch J., Elsner P. et al. Performing patch testing with contact allergens. J. Dtsch. Dermatol. Ges. 2008; 6(9):770-775.
25. Ständer S.T., Rueff F., Summer B. Comparative assessment of nickel sensitization based on medical history, patch test and lymphocyte transformation test. Allergo J. Int. 2014; 23:1

26. Summer B., Paul C., Mazoochian F., Rau C, Thomsen M., Banke I. et al. Nickel (Ni) allergic patients with complications to $\mathrm{Ni}$ containing joint replacement show preferential IL-17 type reactivity to Ni. Contact Dermatitis. 2010; 63(1):15-22.

27. Thienpont E., Berger Y. No allergic reaction after TKA in a chrome-cobalt-nickel-sensitive patient: case report and review of the literature. Knee Surgery, Sports Traumatol. Arthroscopy. 2013; 21(3):636-640.

28. Thomas P., Braathen L.R., Dorig M., Aubock J., Nestle $\mathrm{F}$, Werfel $\mathrm{T}$. et al. Increased metal allergy in patients with failed metal-on-metal hip arthroplasty and periimplant T-lymphocytic inflammation. Allergy. 2009; 64(8):1157-1165.

29. Thomas P., Schuh A., Ring J., Thomsen M. Orthopedic surgical implants and allergies: joint statement by the implant allergy working group (AK 20) of the DGOOC (German association of orthopedics and orthopedic surgery), DKG (German contact dermatitis research group) and dgaki (German society for allergology and clinical immunology). Orthopäde. 2008; 37(1):75-88.

30. Thomas P., Stauner K., Schraml A,. Mahler V., Banke I.J., Gollwitzer H. et al. Characteristics of 200 patients with suspected implant allergy compared to 100 symptom-free arthroplasty patients. Orthopäde. 2013; 42(8):607-613.

31. Thomas P., Thomas M., Summer B., Dietrich K., Zauzig M., Steinhauser E. et al. Impaired wound-healing, local eczema, and chronic inflammation following titanium osteosynthesis in a nickel and cobalt-allergic patient: a case report and review of the literature. J. Bone Joint Surg. 2011; 93-A(11):e61.

32. Thomas P., Thomsen M. Implant allergies. Hautarzt. 2010; 61(3):255-262

33. Thomas P.H., Schopf C., Thomsen M., Frommelt L. Schneider J., Flaig M. et al. Periimplant histology and cytokine pattern in metal-allergic kneearthroplasty patients with improvement after revision with hypoallergenic materials. Sem. Arthroplasty. 2012; 23(4):268-272.

34. Thyssen J.P., Menne T., Schalock P.C., Taylor J.S. Maibach H.I. Pragmatic approach to the clinical workup of patients with putative allergic disease to metallic orthopaedic implants before and after surgery. Br. J. Dermatol. 2011; 164(3):473-478.

35. Wengler A., Nimptsch U., Mansky T. Hip and knee replacement in Germany and the USA - analysis of individual inpatient data from German and US hospitals for the years 2005 to 2011. Ärzteblatt Int. 2014; $111(23-24): 9$.

КОНТАКТНАЯ ИНФОРМАЦИЯ:

Томас Петер - доктор медицины, профессор кафедры дерматологии и аллергологии Мюнхенского университета им. Людвига-Максимилиана. Thomas Peter - MD, professor of Department of Dermatology and Allergology, Ludwig-Maximilians-University, Munich.e-mail: Peter.Thomas@med.uni-muenchen.de 